\title{
Media Archaeology
}


The publisher gratefully acknowledges the generous support of the Humanities Endowment Fund of the University of California Press Foundation. 


\section{Media Archaeology}

Approaches, Applications, and Implications

Edited by

Erkki Huhtamo and Jussi Parikka

무

UNIVERSITY OF CALIFORNIA PRESS

Berkeley Los Angeles London 
University of California Press, one of the most distinguished university presses in the United States, enriches lives around the world by advancing scholarship in the humanities, social sciences, and natural sciences. Its activities are supported by the UC Press Foundation and by philanthropic contributions from individuals and institutions. For more information, visit www.ucpress.edu.

University of California Press

Berkeley and Los Angeles, California

University of California Press, Ltd.

London, England

(C) 2011 by The Regents of the University of California

Library of Congress Cataloging-in-Publication Data

Media archaeology : approaches, applications, and implications / edited by Erkki Huhtamo and Jussi Parikka.

p. $\mathrm{cm}$.

Includes bibliographical references and index.

ISBN 978-0-520-26273-7 (cloth : alk. paper)

ISBN 978-0-520-26274-4 (pbk. : alk. paper)

1. Mass media. 2. Information technology. I. Huhtamo, Erkki.

II. Parikka, Jussi, 1976-

P9O.M36622 2011

$302.23-\mathrm{dc} 22$

2010037380

Manufactured in the United States of America

$\begin{array}{llllllllll}20 & 19 & 18 & 17 & 16 & 15 & 14 & 13 & 12 & 11\end{array}$

$\begin{array}{llllllllll}10 & 9 & 8 & 7 & 6 & 5 & 4 & 3 & 2 & 1\end{array}$

This book is printed on Cascades Enviro 100, a 100\% post consumer waste, recycled, de-inked fiber. FSC recycled certified and processed chlorine free. It is acid free, Ecologo certified, and manufactured by BioGas energy. 